\title{
INDICATORS OF SUSTAINABILITY
}

\author{
BULLA MIKLÓS ${ }^{1}$, GUZLI PIROSKA² \\ ${ }^{1}$ Széchenyi István University \\ H-9026 Győr, Egyetem tér 1., e-mail: bulla@sze.hu \\ ${ }^{2}$ National Environmental Council on the Environment \\ H-1011 Budapest, Fô u. 44-50.
}

Keywords: environmental indicators, sustainability

\section{Introduction}

Under the "KÉP" project we have reviewed national environment indicator development projects. Our assessment is as follows:

\section{General assumptions}

For decades intensive attempts have been made to describe the exact relationship between pressures effecting the environment and changes they cause in the status of the environment. The work presents difficulties as well as practical consequence. A "clear" alignment of impacts (pressure on environment) and effects (responses by the environment) is not possible. Changes in status of the environment generate subsequent impacts. It is important to make an effort to present a well defined, presentation of for information "creators" and also for "-users" at the same time.

The success of policy producing information for decision makers should satisfy both public and private needs. Sustainable Development (SD) Indicators for the public are tools for raising awareness, and our aim is to decrease dissonance between awareness and behaviour (BAULER, 1999).

Indicators are information resources for private individuals and government officials. Their function is to provide information to officials to use for analysing environmental, social-, and economic processes and to give clear information to the public.

It seems that the implementation of the SD depends more on the decision preparing role of the indicators than on their scientific accuracy. This statement assumes that the indicators should be appropriate to different levels of decision making, or user-friendly. Unfortunately there is not enough experience about the nature of the interaction between decision making processes and the indicators of the sustainable development as the elements of the information matrix. Is the application of indicators able to enhance the enforcement of considerations in the "dynamic process" of sustainability in an effective manner?

\section{Role and Function of Indicators}

Unfortunately there are no internationally accepted standards for the system of sustainable development indicators. Many systems of key performance indicators were developed in the last few years, (UN, EU Institutions such as the Statistical Office, 
Eurostat, and the European Environmental Agency EEA, Organisation for Economic Co-operation and Development OECD, and individual national systems.....). These systems are quantified, or mapping based, with a common nature of being complex with numerous elements.

It is possible to group the indicators based on different points of views.

\section{Overview of International Indicator work}

\section{OECD indicators}

The OECD displays the system pyramid of the indicators answering different political questions as shown in the following figure.

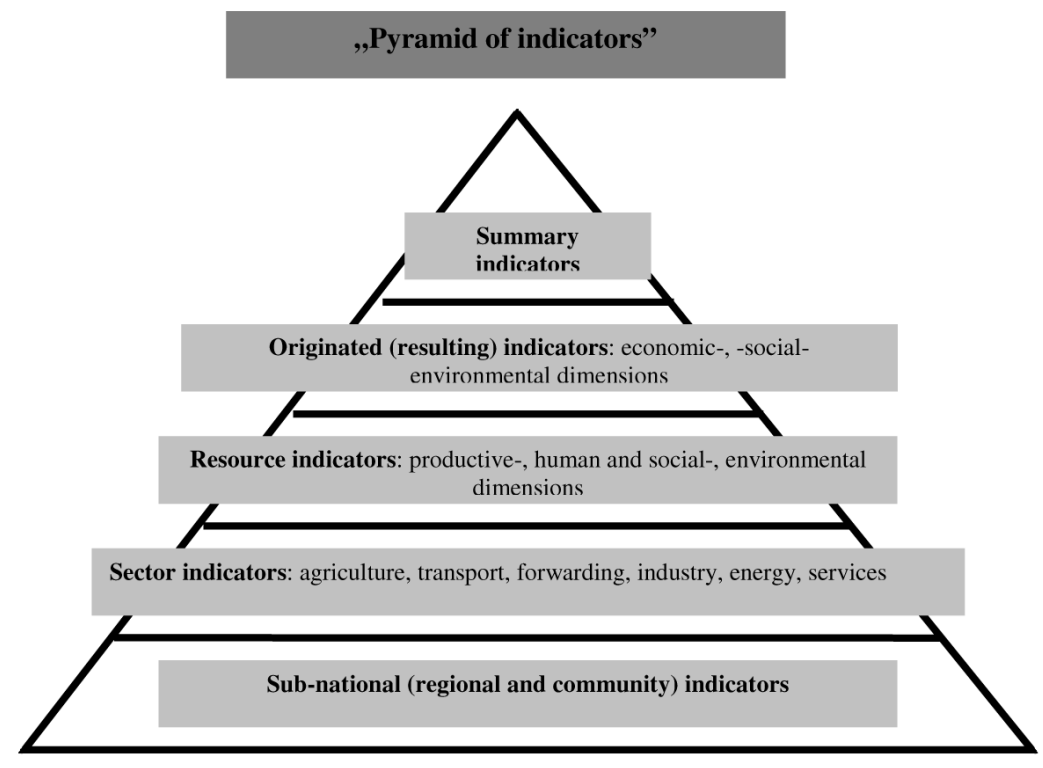

Figure 1. The system pyramid of the indicators as displayed by OECD

1. ábra Az indikátorok piramisrendszere, ahogyan az OECD ábrázolja

\section{Grouping of Indicators according to the EEA}

There are multiple possibilities to group the indicators:

- domain-based

It defines the indicators based on the 3 dimensions (economy-society-environment) of sustainable development. Its advantage is that it assures the dominance of these three aspects. However its drawback is that it tolerates overlapping. 
- goal-based

The selection of the indicator set is determined by the objectives of the research "group". In order to achieve goals, it is important to define the objectives around general issues, and next to define the indicators as sub-categories.

- sector-based

This grouping aims to assist the primary responsibilities of government such as education, housing, transportation, safety and security, and leisure. It is important to work out indexes which assist accountability.

- issue-based

The model focuses more on the principles of sustainability (as economic development, education, water management, suppression of crime), than on local programs. It is well communicated as sector- based models, but its drawback is that it is difficult to combine the aspects of sustainability with it.

- cause-based

The "PSR" model will be detailed further on.

- Combination

It is possible to combine these approaches. For example, a sector based grouping can be transformed to contain categories and sub-categories meeting the requirements of sustainability, and the "PSR" framework as well.

Indicators can indicate directions of non sustainable development.

- Non sustainable indicators

- Climate change

- Depletion of the ozone layer

- Soil degradation and desertification

- Loss of bio-diversity

- Deforestation

- Growing use of non renewable resources

- Growth of poverty, etc.

Such indicators have an announcing and indicative role.

Grouping indicators by their functions makes modelling easier. According to this particular grouping, indicators can be grouped as follows:

- Descriptive indicators

- Efficiency indicators

- Performance indicators (indicators of ecology and economics)

- Total welfare indicators 


\section{Measuring sustainability}

\section{New-type macro indicators}

(I) ISEW was created to eliminate the flaws of the GNP to show a more realistic picture of well being and the economy. ISEW is an improvement on previous methods in two ways. First, it considers the effects of changes in consumption on well being; secondly it includes the net present value (NPV) of the long term environment degradation into the indicator.

The real improvement indicator GPI used in the US is the enhancement of ISEW. GPI is also based on personal consumption in the GDP, modified by the deviation in income distribution, subtracting the different social and ecological costs and adding profits (SZLÁVIK, 2006).

(II) An aggregating indicator, which can be physically interpreted, is the ecological footprint, or the almost identical SPI (Sustainable Process Index) which is noted by Narodoslawkij. It measures the entire site required to sustain the satisfaction of needs in terms of food, water, energy, and waste disposal, per person, products, sites and cities. It is an excellent summary of the main environmental effects of business activity, though it cannot indicate the social aspect of sustainable development.

(III) The sustainability barometer was created as an aggregate indicator of environmental and social components of sustainable development. On this two-dimensional graph the statuses of the ecosystem and human well being are indicated on a relative scale of 0 to 100 , showing the range between good and bad conditions. The point specified by these two values gives sustainability (or un-sustainability).

(IV) The ESI (Environmental Sustainability Index) indicates the progress made towards environmental sustainability. The ESI traces the relative achievements of the countries in the five basic aspects as follows:

- Environmental systems

- The diminishing of stress factors

- The diminishing of human vulnerability

- Social and institutional performance

- Global „care”

The ESI enables us to compare the sustainability attained by countries in a systemized and numerical way. A more exact analysis is possible for decision making because the ESI criteria are strict and this approach is based on measured data.

The ESI enables:

- decisions to be made on issues where the national performance surpasses expectations or lags behind them,

- priorities to be set among the activities within countries and regions,

- environmental trends to be traced,

- the qualitative assessment of the success of environmental policies and programs, 
- a survey of correlations between the environment and business performance and the factors influencing environmental sustainability.

\section{Models of information flow - the method of modelling}

A definition of sustainable development indicators requires a model that assists in specifying the main fields through which processes in the system under investigation can be traced. Modelling by the United Nations, the OECD, the European Union, and the World Bank set off from somewhat different starting points according to their character, but they followed essentially the same methodological track. (CsANÁDY, 1994)

The first Hungarian initiative was very similar to the "Simplified model of environmental management (BULLA, 1993).

The "PSR", pressure - state - response and the "PSIR", pressure - state - impact response model are so far the most commonly used methods that specify indicators. The "PSR" is noted by Albert Adriaanse and Manuel Winograd. This was developed and applied by the OECD in 1994.

\section{The OECD model}

The OECD has specified the following criteria for the environmental indicators in their model:

- political relevance, the satisfaction of user demands,

- properly represent environmental conditions, pressures and the social reaction,

- simple, easy to interpret and capable of managing changes in time,

- sensitive to changes in the environment and in related human activities,

- serve as basis of international comparisons,

- enable national surveys or regional application,

- threshold values are to be specified so that users can compare with them the values received,

- analytical accuracy for the theoretical grounding,

- their validity is tailored to international standards and national agreements,

- can be connected to business models, forecasts and information systems,

- measurability (demands arising in connection with data serving as basis for the indicator),

- data must be attainable at a reasonable cost/benefit ratio,

- proper documentation, the knowledge of quality,

- reliable, regular upgrading.

The model below shows that basic pressures such as changes in population, economic growth and political decisions generate changes at a sector level, which eventually indirectly cause pressure on the environment (changes in the habitat, noise and other pollution) by means of changes in land use or the generation of waste. These effects elicit various reactions publicly and in rules and regulations, which should consequently result in changes at the levels which are affected. 


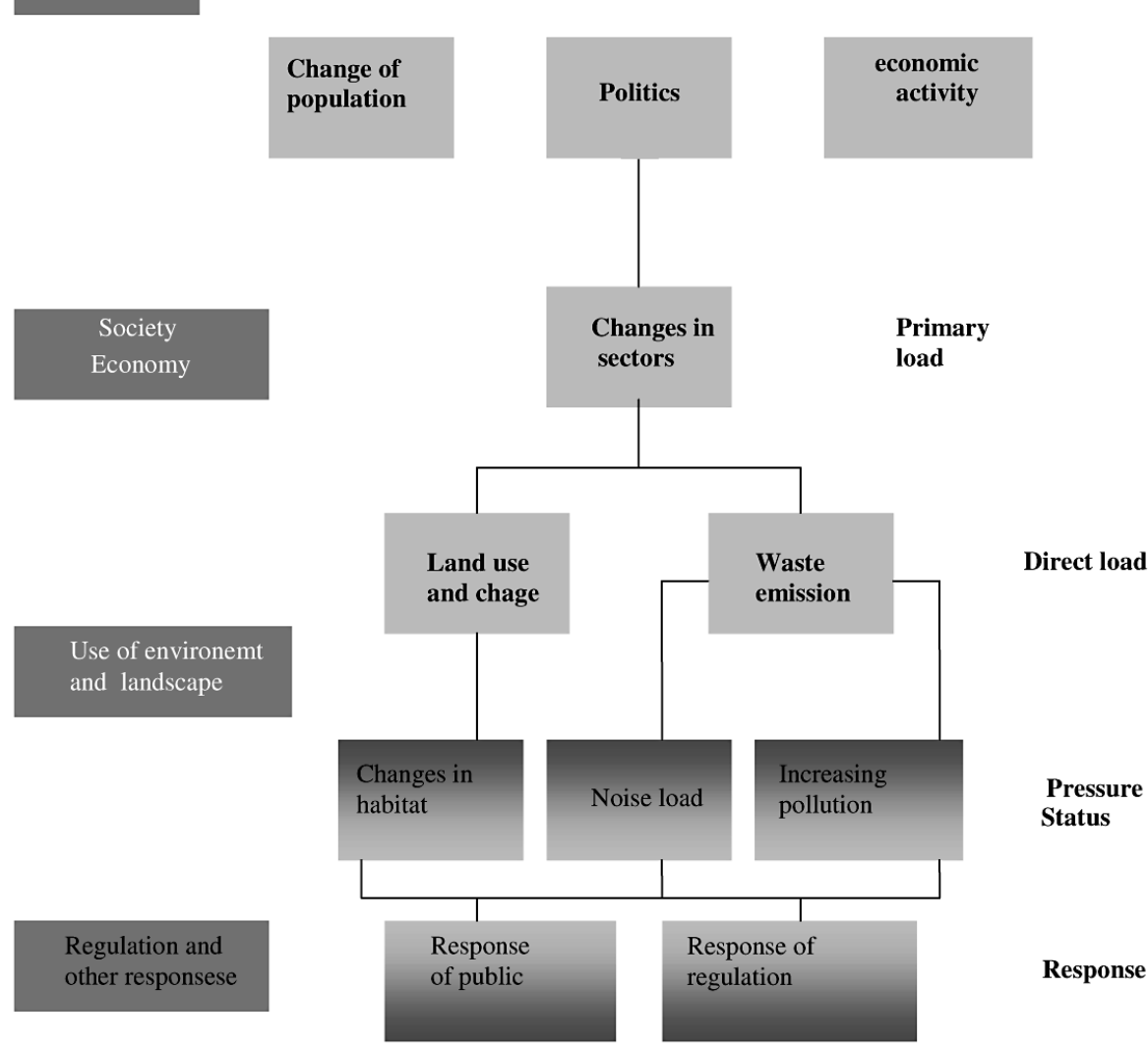

Source: OECD, 1994

Figure 2. The structure of the OECD model

2. ábra Az OECD modell szerkezete

The department of the UK's Ministry of the Environment dealing with sustainable development indicators further extended the "PSR" model with social-business factors in 1996.

However, Hartmut Bossel sharply criticized these two approaches. In his article "Indicators for Sustainable Development: Theory, Method, Applications" he wrote: the disadvantage of the "PSR" and "PSIR" models is that they enable the investigation of only some causes and effects of certain environmental problems." The sharpest criticism of the approach is that it disregards the dynamic nature of the processes. Therefore their incorporation in major systems generates a number of feedback "loops". Therefore it is justified to find solutions for using "soft computing methods" to model non linear complex environmental-social-economic problems (BULLA, 2004). 
In many cases the interpretation of effect-chains on the basis of the "PSIR" as a framework is an inadequate approach. Certain effects appear in the interpretation chain as pressure while in other cases as state. Such definition and grouping problems have been already pointed out by early modelling attempts.

The model cannot handle the complex pressures and effect mechanisms, the real and generally non-linear correlations of the effect-chain.

The conclusion is that meeting the requirements of the indicators, such as rendering basic information on the viability of a system and on changes in its viability, the support of the specified aims and sustainable development are not satisfied by the "PSR" and "DPSIR" models. Therefore a system-based attitude has to be followed while structural indicators are being searched.

The EEA is participating in the assessment of environmental changes in the subject of sustainable development by publishing the Sustainable Development Strategy of the European Union and with the European Commission initiative to prepare a process account on sustainable development for the prime ministers. Indicators to the EU account shall be selected by the elaborators of the methodology. It forms a good basis so that they be asked to give an account on their actions or negligence and this methodology may finally result in "sustainable convergence criteria". The EEA has elaborated a number of tools, frameworks and typologies that enable the comprehensive assessment of changes beside a limited selection of development indicators.

\section{The United Nations model}

In 1993 The United Nations established the System of Integrated Environmental and Economic Accounting (SEEA). The diagram describes correlations between the sustainability concepts and indicators.

The diagram above shows a potential plan of a structure of sustainability concepts and indicators. The quantitative indicators of business are shown in the grey field; the white squares represent the physical and non-financial indicators. Sustainability has been specified as a function of purchase, use and users, thus referring to a possible distinction between sustainability of supply, use and human development. This approach suggests that the basic aim of sustainability is not to simply optimise business activity, but to serve human well being in a complex way. Business sustainability is measured within the structure on the basis of the national accounting system regulated by environmental protection. This includes the ENI (Environmentally Adjusted national Income) and the EDP (environmentally adjusted net domestic product). A non-financial tool measuring sustainability is the $\mathbf{C C}$ (Carrying Capacity of a territory), which means the human population carrying capacity of a given territory.

By April, 1995, the UN Commission on Sustainable Development had drawn up an indicator list, with about one hundred and thirty indicators which are within the "DSR" (driving force - state-response) framework. 


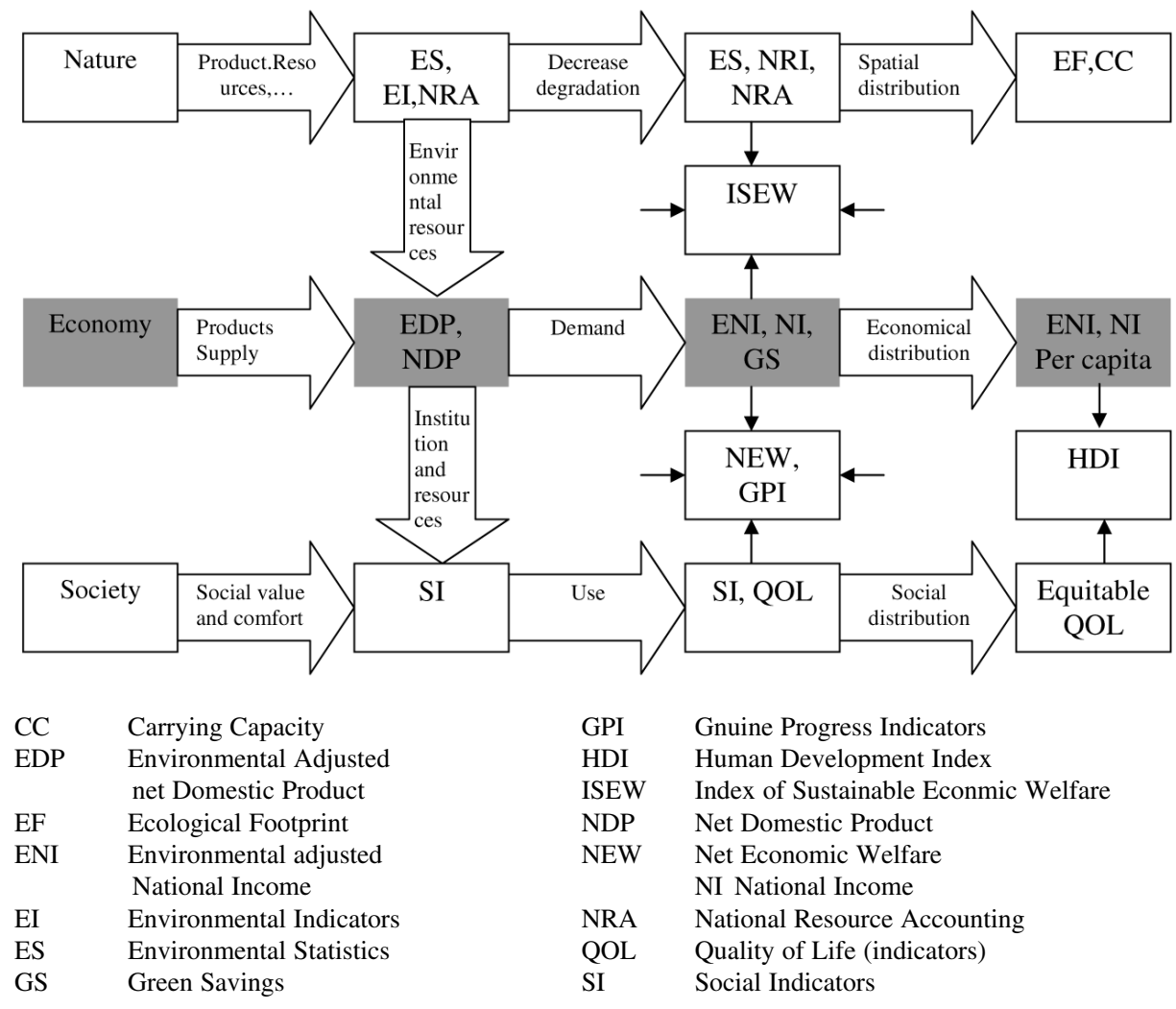

Figure 3. System of Integrated Environmental and Economic Accounting (SEEA)

3. ábra Az Integrált Környezeti- és Gazdasági Számítás Rendszere

The components of the framework are as follows:

- Driving force- human activities, processes and patterns that effect sustainable development

- State - the "state" of sustainable development

- Response - the versions of methodology which can be followed and other responses to changes in sustainable development

Within the DSR framework "pressure" is replaced by "driving force" so that further social, business and institutional indicators may be more exactly inserted into the framework. The use of "driving force" also allows the effect made on sustainable development to be both positive and negative, as in many cases with social, business and institutional indicators.

The DSR framework is a matrix that horizontally shows three indicators, while vertically showing the social, business, environmental and institutional dimensions of sustainable development. 


\section{The EU model (EEA)}

The EEA further developed the models introduced so far, and created the "DPSIR" (driving force-pressure-state-response) indicator structure.

The EU initiatives are very much parallel with UN and OECD research. The program of the European Commission consists of three components: the program of environmental pressure indicators, the creation of EU indicators based on the UNCSD (UN Commission on Sustainable Development) study made with the use of Agenda 21 and a number of projects listed in the general research program of the EU. The 'p-s-r' approach of modelling is reflected by the fact that the social indicators are based on such basic statistical data as population density, migration, public health status, unemployment, urbanisation, etc., compared to the ratio of social effects.

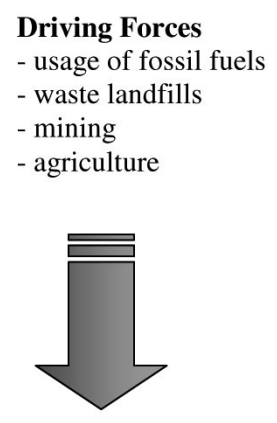

\section{Pressure}

- emission of greenhouse ga

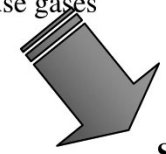

\section{State}

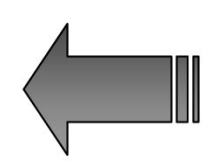

Response

- energy tax

- energy saving programs

- alternative fuels

- recuperation

- reducing fluor-carbon emission

- cc. of greenhouse gases

- means of temperature

- raising sea level

Source: EEA, 1997

Figure 4. The EEA developed DPSIR indicator structure

4. ábra Az EEA által kifejlesztett DPSIR indikátor-szerkezet

In the DPSIR framework the social and business driving forces apply pressure on the environment; therefore the state of the environment also changes, such as public health conditions, the availability of resources and bio-diversity. These all have effects on human public health, on the ecosystem and all kinds of materials being applied by humans. On the other hand, they can elicit a social response that has a feedback on driving forces or directly on the state or effects, by means of adaptation or recuperative activities. Beside the study of the components, correlations between the components can also be studied. The correlation between driving force and pressure corresponds to the 
eco-efficiency of the technology, where a smaller pressure from the driving force accompanies an improving eco-efficiency. Similarly, the effects on people and the ecosystem and the state depend on the pressure-bearing capacity and the threshold values of these systems. Whether society responds to these effects or not depends on how these effects are perceived and assessed, while the effect of the response on driving forces depends on the efficacy of the response.

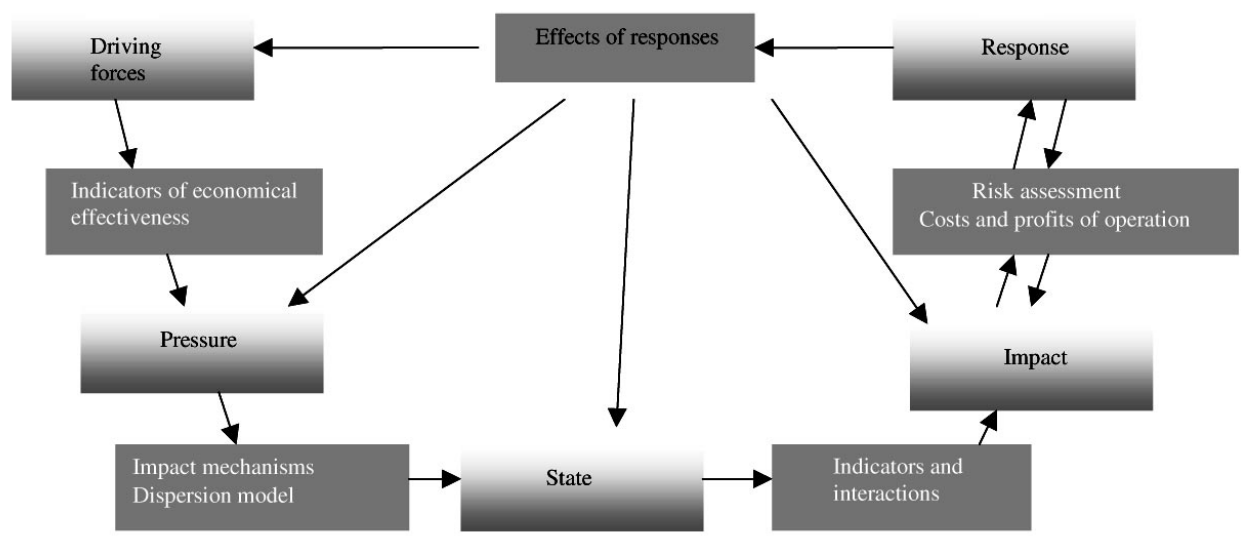

Source: EEA: Technical Report, 1999.

5. Figure The diagram of the effects of responses by EEA

5. ábra EEA diagram a hatásválaszokról

This structure makes clear the relation between the origin and the consequence of environmental problems. They are used for planning, for the formulation of political aims and priorities, for budget calculation, for performance evaluation, and they play an important role in public information. The information flow model of the concept is as follows:

\section{Applications}

\section{Environmental accounts}

Environmental accounts are gradually appearing at all governmental levels and in the business world, too. The type of environmental accounts depends on for whom and for what reason they are prepared. The account is helpful in the organization and representation of information used to define issues detailed in the report. Some examples are:

Reports on the status of the environment, prepared by:

- the World Resources Institute,

- the EU,

- the OECD, 
- Hungary, with the title "Hungarian environmental indicators".

Sustainability reports

- Sustainability Counts and

- Indicators of Sustainable Development, (prepared by the Sustainable Development Commission).

»Corporate reports «

The corporate environmental reports provide information for the community that is affected by the activity of a private or state organization. The list below drafts two types of corporate reporting frameworks.

- State Environmental Reports

- Triple Bottom Line

\section{Regional and Local Governmental Initiatives}

In response to Local Agenda 21 (LA21), a number of governmental levels below the national level have elaborated indicators on sustainable development so that they serve as educational tools, as means to assess the original business situation and as a standard to ensure sustainability. For example, the local governmental level in the UK endeavoured to combine the introduction of environmental control systems with the application of indicators that measure performance.

A significant new component is the subgroup with the 14 key indicators which should draw public attention to what sustainable development means, and is endeavouring to review whether "a better living standard" can be ensured "for everyone now and at future generations".

\section{Corporate Initiatives}

The application of corporate checking indicators preceded the concept of sustainable development. However, only a few business organizations are capable of measuring all of their environmental effects, and even fewer think about social obligations. The current dispute is about choosing between 'eco-balancing' (an objective assessment of all environmental effects) and eco-management (rules specified by the management about supplementary environmental developments). A constant shift can be traced from the satisfaction of external obligations towards the definition of internal management objectives, whose objectives are based on the

'Nothing venture nothing gain' concept of eco-efficiency.

Some of the more promising corporate initiatives are performed by development agencies and associations commissioned to manage selected regional subsidy programs. These agencies and associations include the associations set up for the regional support to be granted for the Structural Funds (SF) ,the Scottish Enterprise network, SEN and the English Regional Development Agencies ERDA . 


\section{The eco-efficiency concept of the WBCSD and their suggested measurements}

The eco-efficiency concept was first used by the World Business Council for Sustainable Development (WBCSD) in its report, which was handed in at the 1992 UNO conference about sustainable development. Since then the meaning of the eco-efficiency concept has widely been debated. According to the definition of the OECD "The eco-efficiency expresses the efficiency with which the ecological resources can are used to meet people's demands." On the basis of the meaning provided by the OECD the ecoefficiency can also be defined as the proportion of production and expenditure where production means the value of goods or services produced by an organisation, and expenditure means the totality of environmental devastation caused by the production.

$$
\begin{aligned}
& \text { The value of goods or services } \\
& \text { Eco-efficiency = ------------------------------ }
\end{aligned}
$$

The eco-efficiency concept was determined by the WBCSD in the following way:

We can achieve eco-efficiency if we provide such goods or services at a competitive price which meet people's demands and improve the quality of life as they try to decrease environmental impacts and the intensity of the use of resources during the life cycle to a level suitable for the Earth's estimated carrying capacity.

\section{Environmental Communication}

Environmental communication is in close relationship with sustainable development, with its success. It is based on accessible, accurate, reliable, sufficient information and on the traceable information flow. The demand for it was first worded at the 1972 Stockholm conference but almost a decade had passed when this wish was made into a directive in the European Union (Council Directive 90/313/EEC of 7 June 1990 on the freedom of access to information on the environment).

The $5^{\text {th }}$ programme of action of the EU, the RIO Declaration on Environment and Development and the Agenda 21 approach and interpret the environmental communication in a more comprehensive way. A further step in this context is the Aarhus agreement which regulates three basic questions:

- the right of private individuals and legal entities to be informed in connection with environmental questions

- the public's right to participate in decision making concerning environment protection

- an introspection to the litigation in case any of the previous two rights is violated

This declaration was amended with an agreement in 2000 which allows the public access to environmental information electronically.

It seems to still have a big gap between the information deriving from the environment and their use. In 1998 the EEA in its Expert Corner Report initiated the modification of the communication model in order to have environmental information which really extends knowledge of the environment and has a real role in decision preparation.

This model also needs to be further elaborated in more details in order to accomplish 
the more efficient application of research results and computer applications.

In May 2006 the EEA organised a workshop entitled "Research communication in Environmental Sustainability Research" in Stockholm where the participants conferred about conveying the results of researches concerning sustainable development to the different characters of the society. At the conference F. Hinterberger, the president of the Sustainable Europe Research Institute presented the "Mosus project" elaborated by the Institue. This project aims at finding out the possible ways of producing more and more values from less and less resources. (HINTERBERGER, 2006) in the course of the the same workshop, McGlade (DG. Env.) gave an account of the actual status of the communication of socio-ecological researches (MCGLADE, 2006).

\section{Environmental Information on the Internet}

There are diverse supporting systems to aid the access to international researches and databases concerning environmental information. It can be considered as a step forward that the European Union has begun to support the telematics applications through its 4th Frame Programme.

The EEA plays an important role in the development of the database available on the world-wide web. A system of meta-information, Catalogue of Data Sources (CDS) has been elaborated, and with the participation of some European countries the Environmental Information and Observation Network (EIONET) has been developed. Besides them, with the help of the European Topic Centre on Catalogue of Data Sources they created the Directory of Information Resources, DIR) the Environmental Locator Catalogue which contains the attainability of environment information traceable all over Europe. The previously mentioned EIONET was elaborated as its thematic part and also the European Topic Centre on Catalogue of Data Sources (SERIS) together with EEA publications and other national reports on the status of the environment. The Sustainable Targets and Reference Value Database were also worked out by the EEA.

There are other national databases available, such as the German Environmental Information Network (GEIN).

The International Institute for Sustainable Development (IISD) has developed a Compendium, an electronic database which plans to "record", summarize the organisations, researchers and workshops dealing with indicators and their areas.

The IISD elaborated a visual model ("Dashboard of Sustainability"), more precisely a device panel which presents the present status of certain countries in the sustainable development in a spectacular way - mainly in the form of diagrams.

The operation of the model is simple as it is detailed but it contains adequate information to make it possible to identify the resultant of certain problems without knowing accurately the operation of the entire system. The Dashboard contains 46 indicators for approximately a hundred countries, which have been classified in the three main clusters (economy, society, and environment).

The model needs development in more respects. The database was criticised for not being able to operate the constant growth of the hoard of data, and for not making it possible to carry out an online analysis. It has been proposed to have the indicator kit replaced by a range of indicators chosen on the basis of consensus which regards and summarizes the opinions of communities, countries or international experts. 


\section{Applications in Hungary}

The first organized environmental status assessment was prepared in 1988-89, with a simple structure, in order to support the establishment of priorities for displaying the status of the environmental elements and systems and qualifying the tasks to be done. In 1990 the foundation of complex environmental assessment methods was born with the definition of the environmental status, environmental trends, and the problems of a complex evaluation system designed to determine the information regarding the relation of economic activities in production and services - determining the direction of the elaboration.

The "environmental problem space" model, the "simplified model of environmental, management and analysis" (BuLLA, 1993) and the program was established to record the status of the environment. The parameter set, the required IT support system and suitable system of evaluation criteria was defined.

In 2001, the joint programme of the Ministry for Environment and Water and the Hungarian Academy of Sciences published its report on the economic evaluation on the environmental effects of air pollution. It was coordinated by the Institute of Soil and Agro-chemistry. The project mapped and summarized the achievements of the different professional fields connected to the topic. An integrated system and a model were built to analyze the social and economic effects of air pollution.

A "fact book" was published without using the results of the first methodological research and developments. It offered:

- Data on the environmental status of Hungary (yearly or biannually from 1996)

- Environmental statistics data (NSO 1996, 2000)

- Environmental indicators of Hungary (SZABó and PomázI, 2002.)

The data is rich but the information content of the indicators is richer, because it contains the causes as well as the results. All of these can regarded as proper recordings of the status and are inevitable, but cannot substitute the evaluation which includes the effects and the tendencies and which can be the basis of reasonable management of the environmental resources.

After the first steps in recording the status of the environment, the analytical scientific knowledge of the different fields was evolved, as indicated by the publications issued on the topic.

Significant achievements have been made in the exploration and the documentation of the processes and connections - as well as in the development (BULLA, 2003). 


\section{References}

BAUleR, T. 1999: Concept, Application and Validation-Efficiency of an ,environmental system” Indicators for sustainable development in an inter-regional context, Brussels

Bulla, M. 1993: Environmental Analysis (Környezetelemzés), PhD Thesis, kandidátusi értkezés, MTA

Bulla, M. 2003: Evaluation methods and tools for sustainable development. Conference Proceedings. Manchester

Bulla, M. 2004: Methodological Improvement of Complex Environmental Status Assesments, Sz.E. Environmental Engineering Department, p. 129.

CSANÁDY, R. A. 1994: Elaboration and application of international endeavours to display indicators of sustainability in Hungary, Maastricht

ENVIRONMENTAL InDICATORS 1999: Typology and overview (EEA Technical Report), Copenhagen

Hinterberger, F. 2006: Dematerilisation for a Sustainable Europe, EEA workshop, Copenhagen.

Indicators of Sustainable Development Framework and Methodologies, UN 1996, New York

MAJOR EFFORTS TOWARDS SUSTAINABLE DEVELOPMENT INDICATORS: CASE STUDIES UN, 1996.

MCGLADE, J. 2006: Research communicatopn in social-ecological systems - a basis for sustainability policy and assessments, EEA workshop, Copenhagen

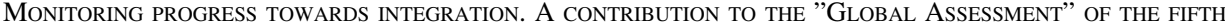
Environmental Action Programme of the EU, 1992-1999 Executive Summary EEA 1999.

Szabó, E, PomÁZI, I. (eds.) 2002: Environmental Indicators of Hungary (Magyarország Környezeti Mutatói), KvVM

SzLÁVIK, J. 2006: Sustainable or risk society (Fenntartható vagy kockázati társadalom) In: Ma \& Holnap folyóirat V. évfolyam 8. szám Különszám

WBCSD, Measuring Eco-efficiency — A Guide to Reporting Company Performance Geneva, 2001. 